\title{
Psammoma Bodies in Cervical Cytology of Nigerian Woman
}

\author{
Wilson I. B. Onuigbo* \\ Department of Pathology, Medical Foundation and Clinic, 8 Nsukka Lane, Enugu 400001, Nigeria.
}

\begin{abstract}
Received: September 25,2016; Accepted: October 07,2016; Published: November 17,2016
*Corresponding author: Wilson I. B. Onuigbo, Department of Pathology, Medical Foundation and Clinic, 8 Nsukka Lane, Enugu 400001, Nigeria, Tel: +2348037208680; Email: wilson.onuigbo@gmail.com
\end{abstract}

\begin{abstract}
The presence of psammoma bodies in cervical smears is a rare finding. A case of it was reported from a Manchester cytology centre in the UK. Therefore, a case found in a Nigerian centre is worthy of report. So was the case of tuberculosis discovered during a local Pap smear campaign.
\end{abstract}

Key words: Cervix; Cytology;Psammoma bodies; Nigeria

\section{Introduction}

The importance of cervical screening is a worldwide issue. Recently, an oddity that turned up at the Manchester Cytology Centre in the United Kingdom was the psammoma body [1]. It was published in order "to alert cytopathologists, to the possibilities, on finding psammoma bodies in cervical smears and the management of these cases." Accordingly, a case occurring in woman of the Igbo Ethnic Group [2] in Nigeria is deemed to be reportable.

\section{Case Report}

RA, a 62-year-old, para 6, post-menopausal woman of the Igbo Ethnic Group [2] attended the local screening centre whose slides I read. She was previously wearing a loop which was removed following bleeding. She was also found to be a diabetic on treatment. Her slide; see the Figure, showed the presence of psammoma bodies. She has been healthy on follow up.

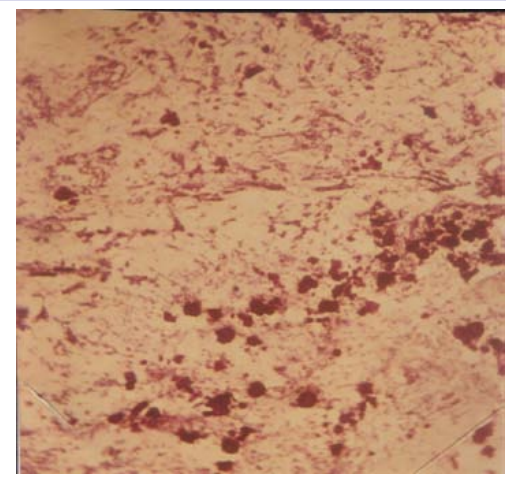

Figure 1: Psammoma bodies.

\section{Discussion}

Pusiol's associates [6], follow up revealed incipient malignancy. Internet sources were considered. Muntz and associates [3] concluded that "our study suggests that the presence of psammoma bodies in normal cytologic smears of asymptomatic women is an incidental finding." In another study [4], the conclusion was also instructive, namely, "There is a strong argument that all women with psammoma bodies on cervical smear should undergo smear review, pelvic ultrasonography, hysteroscopy and biopsy, and laparascopy to exclude the presence of a gynecological malignancy." Cameron and McCluggage [5] added a curious feature, namely, uterine serous carcinoma with bilateral ovarian metastasis, "which was associated with widespread extensive psammonatous calcification of the uterine leiomyomata, the myometrium, and the cervical stroma." In the recent paper of

Follow up was certainly uneventful in our present case, but it requires to be recorded. So was my paper with some local associates [7], tuberculosis having been discovered during the usual Pap smear campaign. Incidentally, in a 30-year-old married Indian female [8], it appears that follow up was not remarkable.

Interestingly, in the report of Parkash and Chacho [9], they opined that psammoma bodies found in a young patient merits a thorough examination, but not surgical exploration in the absence of additional clinical findings or atypical cells.

\section{References}

1. Joseph P, Rana D, Marshall J, Desai D. Significance of psammoma bodies in cervical cytology. J Pathol. 2006;17(6): 399-401. doi :10. 1111/j.1365-2303. 2006.00385.x.

2. Busden GT.Niger Ibos. London:Cass. 1966.

3. Muntz HG, Goff BA, McGonigle K, Isaacson C. The significance of psammoma bodies in screening cervical cytologic smears. Am J Obstet Gynecol. 2003;188(6):1609-1612. DOI: 10.1067/mob. 2003.392

4. Nicklin JL, Perrin L, Obermair A et al. The significance of psammoma bodies on cervical cytology smears. Gynecol Oncol. 2001;83(1): 6-9.

5. Cameron RI, McCluggage WG. Extensive psammomatous calcification 
of the uterus and cervix associated with a uterine serous carcinoma. J Clin Pathol. 2004;57(8):888-890. doi: 10.1136/jcp.2004.017004.

6. Pusiol T, Parolari AM, Piscoli L, et al. Prevalence and significance of psammoma bodies in cervicovaginal smears in a cervical cancer screening program with emphasis on a case of primary bilateral ovarian psammomacarcinoma.CytoJournal. 2008;5:7. Doi:60.1186/17426413-5-7.

7. Onuigbo WIB, Esimai B, Nwaekpe C, Chijioke G. Tubercular endometritis detected through Pap smear campaign in Enugu, Nigeria. Pan Afr Med J. 2012;11:47-48.

8. Seth A, Gupta K, Mathur A, Pant L. Incidental detection of psammoma bodies in cervico-vaginal smears. J Cytol. 2013 Oct-Dec;30(4):272-273. doi: 10.4103/0970-9371.126665

9. Parkash V, Chacho MS. Psammoma bodies in cervicovaginal smears: Incidence and significance. Diagn Cytopathol. 2002;26:81-86. doi:10.1002/dc.10058. 